\title{
Introduction: Precariousness, Community and Participation
}

\author{
Matthew Johnson ${ }^{1}$ \\ Lancaster University
}

This is an Author's Original Manuscript (AOM) of an article published by Taylor \& Francis in Global Discourse on [date of publication], available online: http://www.tandfonline.com/[Article DOI].

This issue of Global Discourse represents the culmination of a series of collaborations exploring 'precariousness' stemming back to 2013 - the year in which we last published an issue on the topic (see Johnson 2013). Here, we attempt to explore the effects of neoliberalism on particular forms of community through the work of participants in "A Cross-Cultural Working Group on "Good Culture" and Precariousness', a participatory project involving academics, community co-researchers and community professionals from a range of backgrounds. The notion of precariousness has been popularized by Guy Standing (2011) to describe the unpredictable neoliberal conditions faced by radically different people throughout the world. Members of Standing's 'precariat' lack occupational identities, treat work and other money-making activities instrumentally, are focused on the short-term and have no 'shadow of the future' hanging over their actions, leaving little incentive to sustain long-term relationships and productive, but unpaid, social activities.

The broader project from which this special issue is drawn sought to examine these conditions through participatory engagement with community co-researchers from Ashington, Northumberland and Aboriginal communities around Brisbane, Australia. While the groups are radically different, there are similarities in traditional cultural commitments and the effects of neoliberalism that give the groups grounds for collaboration in examining political responses to their exclusion. The two groups worked, during visits to each other's communities, with academics and others to explore means of advancing policy grounded in traditional cultural commitments that served them well at various points in their histories. That work led into a British Academy Rising Star Engagement Award-funded series of three conferences on participatory research. These conferences (videos of which are available on the project website: http://wp.lancs.ac.uk/good-culture/), advanced a range of related discussions regarding the challenges that an increasing number of people from an increasing number of backgrounds face. The demographics of the participants in those conferences expanded beyond the original cohort, drawing in academics and community professionals from parts of the UK, Ireland, Iceland and Australia.

This issue traces some of the discussions between the participants and presents an interdisciplinary account of the challenges faced at a time in which neoliberalism seems unchecked and uncheckable by the rise of nationalist populism. The first article, by Gibson Burrell (2017), explores the past, present and future of coal mining towns at a time in which their productive function is eroded in industrialised societies, but relatively buoyant in societies such as India and China. In response, Paul Edwards (2017) reflects upon his own work on mining communities and the concept of the 'isolated mass'. In the second article, Joe Finnerty and Cathal O'Connell (2017) outline the effects of neoliberalism on housing across both communities and classes. Highlighting the way in which young people are now actively

\footnotetext{
${ }^{1}$ m.johnson@lancs.ac.uk
} 
deprived the possibility of certainty and permanence in satisfying this most basic of needs, they present a picture of an Ireland ill-equipped to deal with its recent history of property speculation. Kelly Greenop (2017) highlights broader trends in response. Focusing on a particular example of precarity in housing, Jo Richardson (2017) examines the effects of insufficient accommodation on Gypsy and Traveller groups. Richardson shows that even groups traditionally committed to transitory lifestyles are increasingly prevented from securing predictable and appropriate forms of housing. In response, Ryan Powell (2017) examines a number of related concepts, while Siobhan O'Dowd and Denis Barret (2017) draw on their experience of working with Traveller groups in Ireland in their reply. Siobhán Ó'Sullivan, Séamus Ó'Tuama and Lorna Kenny (2017) then consider the precariousness of education, arguing that universities have a responsibility to deal with exclusion and alienation. Ann-Marie Houghton (2017) offers an overarching analysis of that responsibility, while Tom Fellows (2017) examines issues affecting practice in the UK.

The issue then considers the way in which these sorts of conditions affect the capacity for cooperation and collaboration. Valdimar J. Halldórsson (2017) works through the examples of community engagement with Local Authorities and the Red Cross in the Westfjords of Iceland to consider the conditions under which collaboration can occur, advancing an 'affectbased' account of participation. In reply, Elizabeth Campbell (2017) considers the role of affect in ethnographic work. Finally, John Lazarus (2017) draws upon the evolutionary psychological literature to present an account of co-operation under conditions of adversity. John Baker (2017) replies, fostering cross-disciplinary conversation between political theory and natural science.

While not comprehensive, the issue offers insights into the range of quandaries that communities and political bodies must consider as they deal with the challenges of a world full of bleak alternatives. It is my hope that the issue will serve to strengthen and advance the discussions developed over the project's past five years. In that regard, I must thank the following for their help during that time: 98.9FM; Aboriginal and Torres Straight Islander Indigenous Community Health Service; Adam Iqbal; Adam Luke; Al Jazeera; Alexandra and John Copley; Alex Croom; Alison's Apartments; Alastair Stark; Andrew Parkin; Andrew Thomas; Arbeia Roman Fort and Museum; Ashington Community Football Club; Ashington Community Development Trust; Ashington Life Centre; Ashington Men in Sheds; Bar Loco; BBC Look North (North East and Cumbria); BBC Radio Newcastle; Bogaine Spearim; Brightmoon Media; Brisbane Indigenous Media Association; British Academy; Cameron Parsell; Chrissie O'Sullivan; Christopher Macleod; Christopher May; Clare and Steve Flynn; Community Organisers; Connie and Tommy Johnson; Dale Ruska; Deborah Tait; Denis Barrett; Dennis, Wendy and Anthony McCartney; Durham Miners Association; Egle Dubankaite; Frank Dawes; Fulcrum Arts and Research; GDR PR; Ged Henderson; Gibson Burrell; Great North Museum; Ian Lavery MP; Inala Wangarra; ID\&D: Indigenous Directions and Development; James at Survivaltraininguk.co.uk; John Baker; John Chalmers; John Lazarus; John McVan; John O’Sullivan; Johnny Handle; Norm Sheehan; Keith Shaw; Kelly Greenop; Kevin Robson at Wild Dog Outdoors; Leslie Condon; Lesley van Moelenbroek; Lilla Watson; Linda O'Keeffe; Linus at Northern Wilds; Louise Bennett; Mark Wood; Michael Thewlis at ERC; Morgan Brigg; Murri Mura Aboriginal Corporation; Neil Taylor; Newcastle Sunday Assembly; News Post Leader; Northumberlandia, which is managed by The Land Trust with the support of the Northumberland Wildlife Trust; Red Text Films; Richard Baguely; Richard Cullen; Roger Appleton; Rosie Mutton; Sarah Howarth; Séamus Ó Tuama; Simon Mabon; Steve Harmison; Sue Mendus; System Gallery; The Evening Chronicle; The Journal; The Ration Shed Museum, Cherbourg; The Sunday Sun; Tiger Bayles; Tobias Raub; Traveller Visibility Group, Cork; Tynemouth Cricket Club; Tyneside Cinema; University College Cork; Wansbeck Disability Forum; Woodhorn Museum; Yugambeh Museum. Special thanks to: 
Tom and Kay Johnson; Carolyn Gallagher; Fiona Rowley; Katherine Young, who provided tireless support for organisation of the conferences; Rosie Mutton, who helped to organise and run the conferences and to construct the YouTube archive; Robert Geyer and Patrick Bishop, who accommodated and supported eccentric and complicated work plans with sage-like understanding and compassion; Lancaster University Travel Team, who have dealt with so many requests with such patience, Amran Ghoni, Graham Winwood and Jill Sanctuary; Lancaster Procurement Team: Sarah Metcalfe, Susan Flynn and Suzanne Pritchard; Lancaster University Accounts Payable: Georgia Faloone and Janet Wood; Lancaster University Finance Team: Sharon Jennings and Jonathan Dutton, and Lancaster University Press Office: Beth Broomby, Anne Rothwell, Russell Reader, Vicky Tyrrell, Gillian Whitworth, Ian Broydon and Laura Mitchell

\section{References}

Baker, J. (2017) 'Reply to Lazarus', Global Discourse, 7:4

Burrell, G. (2017) 'The Role of Coal Mining Towns in Social Theory: Past, Present and Future', Global Discourse, 7:4

Campbell, E. (2017) 'Reply to Halldórsson', Global Discourse, 7:4

Lazarus, J. (2017) 'Co-operation in Adversity: An Evolutionary Approach', Global Discourse, $7: 4$

Edwards, P. (2017) 'The Isolated Mass and Contemporary Social Theory', Global Discourse, $7: 4$

Fellows, T. (2017) 'Reply to Ó'Sullivan and Ó’Tuama', Global Discourse, 7:4

Finnerty, J. and O’Connell, C. (2017) 'Precarity in Housing: the Irish Case', Global Discourse, $7: 4$

Greenop, K. (2017) 'Reply to Finnerty and O'Connell', Global Discourse, 7:4

Halldórsson, V. J. (2017) 'Collaboration: How, When and Where?', Global Discourse, 7:4

Houghton, A.-M. (2017) 'Reply to Ó'Sullivan and Ó’Tuama', Global Discourse, 7:4

Johnson, M. T. (2013) 'Introduction', Global Discourse, 3:3-4, 385-387.

O'Dowd, S. and Barret, D. (2017) 'Reply to Richardson', Global Discourse, 7:4

Ó’Sullivan, S., Ó’Tuama, S. and Kenny, L. (2017) 'Responding to Educational Precarity', Global Discourse, 7:4

Powell, R. S. (2017) 'Reply to Richardson', Global Discourse, 7:4

Richardson, J. (2017) 'Precarious Living in Liminal Spaces: The Results of Insufficient Accommodation for Gypsies and Travellers', Global Discourse, 7:4

Standing, G. (2011) The Precariat, London: Bloomsbury. 